\title{
Miljoscenarier
}

\section{- kunsten at lave og bruge forudsigelser}

Af geolog Per S. Sundberg

Forudsigelser af miljøudviklingen benyttes af politikere og embedsmænd til at formulere ny politik og af organisationer og borgere, der gerne vil vide, hvordan fremtidens miljø kommer til at se ud. Bogen "Miljøscenarier" giver en forklaring på, hvad forudsigelser er, hvordan de bliver til, og hvordan de kan bruges.

Bogen "Miljøscenarier" er netop udkommet som den 6. i serien Miljøbiblioteket. Den er udarbejdet af medarbejdere fra Danmarks Miljøundersøgelser og er en let og læsevenlig bog, der dog har sine skønhedsfejl.

\section{Bogens opbygning}

Bogen er opbygget af syv korte kapitler. Kapitel et og to giver en beskrivelse af baggrunden for at lave forudsigelser, hvad de bliver brugt til, hvem der bruger dem, og hvilke forudsætninger der skal være i orden, for at man kan udarbejde dem.

Kapitel tre og fire beskriver forskellige typer forudsigelser og de begreber og metoder, der anvendes, samt hvordan man kommer fra en forudsigelse af samfundets udvikling til en forudsigelse af denne udviklings konsekvenser for natur og miljø.

Kapitel fem og seks giver eksempler på forudsigelser af udviklingen inden for landbrug og trafik, og hvordan disse kan bruges til at belyse miljøkonsekvenserne. Endvidere gives der eksempler på, hvordan komplekse problemstillinger kan forenkles, så bestemte spørgsmål kan belyses og analyseres ved hjælp af forudsigelserne.

Kapitel syv beskriver nogle af de problemstillinger, der kan være, når man bruger forudsigelser, samt hvilken rolle forudsigelser kan få i fremtiden.

\section{Informativ bog}

Bogen giver et godt indblik i, hvordan forudsigelser på det nærmeste er en videnskab en ligning med mange variabler, og at de er et nyttigt redskab i forskellige sammenhænge. Men det fremgår også, at anvendelsen af forudsigelser er stigende, hvoraf følger, at "kvaliteten" af forudsigelserne skal være høj - de skal være konsistente.

Man berører også kort det vigtige og interessante problem, at forudsigelser kan

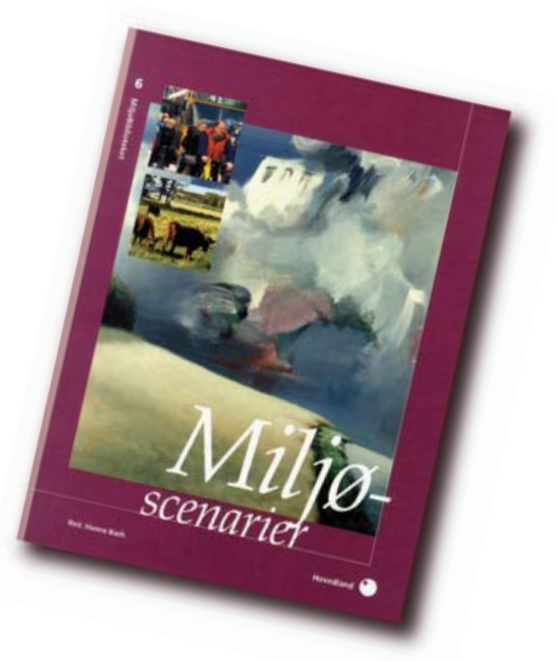

skel synes at være i nogle tal for udslippet af $\mathrm{CO}_{2}$, som Danmark ifølge Kyotoprotokollen har forpligtet sig til at reducere. Her havde det helt klart været pænere med et rettelsesblad.

Ovenstående tyder alt $\mathrm{i}$ alt på en ikke helt grundig gennemarbejdning af materialet og en mangelfuld korrekturlæsning. Og det er synd for en ellers informativ bog.

Miljøscenarier er redigeret af Hanne Bach og med bidrag af Hanne Bach, Henrik Gudmondsson, Jesper S. Schou, Bernd Münier og Jytte B. Illerup. Udgivet af Forlaget Hovedland i samarbejde med Danmarks Miljøundersøgelser, 71 sider, kr. 138, ISBN 87-7739-736-3. være politisk farvede. Bogen beskriver de komplicerede sammenhænge på en let og læsevenlig måde ledsaget af mange fotos og figurer.

\section{Surt opstød}

Skulle man komme med et mavesurt opstød, synes jeg, at mængden af især fotos er lige $\mathrm{i}$ overkanten og ikke altid nødvendige for forståelsen. Piller man for eksempel illustrationerne ud af kapitel 4, er der ikke engang tekst til to sider. Det er lige i den tynde ende til at kunne bære et helt kapitel.

Alle billeder (af uforklarlige grunde på nær nogle i forordet samt kap. 5 og 7) og grafer er nummeret som figurer. Men teksten henviser aldrig til fotografierne, hvorfor en nummerering af disse er helt overflødig. Enkelte af graferne henvises der heller ikke til (fig. 3-3, 4-3, 5-5, 6-1). Endvidere har flere figurer samme nummer (kap. 1).

Den vågne læser formår dog nok at koble tekst med figurer, men det virker noget sjusket og tilfældigt. Endvidere savner man en lille ting som en angivelse af, på hvilke lokaliteter de forskellige billeder stammer fra, selv om det ikke er særligt relevant for den sammenhæng, de er bragt $i$.

I mit eksemplar er der på side 51 (lettere skævt) anbragt en stor label hen over tekstens sidste afsnit. Den oprindelige tekst lader sig dog nemt læse, og den eneste for- 